\title{
SEKTOR PERBANKAN di COVID-19
}

\author{
Ashinta Sekar Bidari ${ }^{1}$, Frans Simangunsong ${ }^{2}$, Karmina Siska $^{3}$ \\ Email : ashintasb@unsa.ac.id, frans@unsa.ac.id,karmina.siska01@gmail.com
}

\begin{abstract}
ABSTRAK
Pandemi Covid-19 membuat pemerintah membuat kebijakan semi-lockdown, dimana adalam kebijakan ini semua aktivitas akan dilakukan dari rumah, misalnya belajar dari rumah, bekerja, beribadah dan sebagainya akan dilakukan dari rumah. Guna dari kebijakan ini adalah agar masyarakat dapat menerapkan social distancing. Namun kebijakan lockdown ini bertentangan dengan industri tertentu yang tidak dapat melakukan pekerjaan dari rumah, seperti ojek online dan pedagang kaki lima, dimana para industri tersebut tidak bisa mendapatkan pemasukan jika hanya berdiam dirumah. Hal itu akan mempengaruhi ekonomi masyarakat dan menimbulkan masalah bagi debitur yang telah melakukan peminjaman dalam perbankan. Oleh karena itu, dalam hal ini pemerintah membuat stimulasi dalam bidang perbankan bagi masyarakat debitur yang terdampak Covid-19. Sejauh ini, kinerja perbankan dapat dikategorikan masih dalam keadaan baik dan masih terjaga meskipun sedang terjadi wabah Covid-19 ini. Namun jika dalam waktu yang panjang wabah ini belum juga terselesaikan, maka keadaan kinerja ekonomi perbankan kemungkinan akan mengalami penurunan atau memburuk. Karena keadaan kinerja perbankan untuk beberapa bulan bahkan beberapa tahun kedepan akan sangat bergantung kepada bagaimana penanganan Covid-19 dimasa sekarang.
\end{abstract}

Kata kunci : Covid-19, Kebijakan Pemerintah, Kinerja Perbankan

\footnotetext{
${ }^{1}$ Penulis adalah Dosen Fakultas Hukum Universitas Surakarta

${ }^{2}$ Penulis adalah Dosen Fakultas Hukum Universitas 17 Agustus 1945 Surabaya

${ }^{3}$ Penulis adalah Mahasiswa Fakultas Hukum Universitas Surakarta
} 


\section{PENDAHULUAN}

Wuhan, China merupakan kota pertama Pandemi Covid-19 muncul di akhir tahun 2019. Dari hasil penelusuran bahwa yang terkena virus tersebut adalah masyarakat yang mengunjungi pasar tersebut yang menjual makanan laut dan aneka hewan yang ada di Wuhan. ${ }^{4}$ Secara kodrati, manusia sebagai makhluk sosial yang melakukan interaksi dengan orang lain sehingga penyebaran Covid-19 semakin meningkat.Di Indonesia sendiri perkembangan virus corona baru masuk di bulan Maret tahun ini. Masuknya virus Covid-19 itu berdampak pada sektor ekonomi, anjloknya bursa saham, pelaku usaha mengalami stagnansi serta nilai rupiah yang anjlok.Perekonomian di Indonesia dapat masuk dalam skenario terburuk apabila tidak mampu mengatasi efek pandemi ini.

Adapun risiko-risiko yang dihadapi oleh Indonesia antara lain kenaikan equity risk premium, suplai tenaga kerja yang turun, biaya produksi yang meningkat, permintaan yang turun, dan anggaran belanja. Adanya masa karantina selama 14 hari maka apabia pekerja semakin banyak yang terinfeksi maka semakin tinggi pula beban perusahaan untuk menanggung biaya produksi.Keadaan semakin buruk dengan adanya impor bahan baku dan barang modal yang terhambat dari Tiongkok yang menjadi pusat pandemi.Pada akhirnya terjadi kenaikan harga barang serta diikuti dengan pendapatan masyarakat yang menurun, terjadinya PHK merupakan penyebab daya beli juga menurun. Pemerintah harus melakukan kebijakan-kebijakan dalam rangka mengantisipasi daya konsumsi yang terus merosot. Perekonomian Indonesia pada 2020 dan tahun-tahun mendatang akan dipengaruhi pada penanganan pandemi virus corona.

Di Era globalisasi saat ini kualitas hidup masyarakat yang meningkat di Indonesia merupakan tujuan dalam program pembangunan. Peningkatan kualitas kehidupandapatterwujud dengan peningkatan pendapatan melalui kegiatan-kegiatan

${ }^{4}$ Alin Agustin, "Dampak Pandemi Covid-19 Pada Pertumbuhan Ekonomi Indonesia",Bale Warga, Sabtu, 28 Mar 2020, pukul 12:40 WIB. perekonomian. Sektor perbankan meruakan peranan yang strategis dalam kegiatan perekonomian. Hal itu dikarenakan, bank memegang fungsi sebagai FinancialIntermediary, yaitu suatu media penghimpun dana dan penyalur dana masyarakat. Perbankan merupakan lembaga yangtelah lama memberi warna pada kegiatan perekonomian negara. Eksistensi perbankan di era perekonomian modern sebagai lembaga media/perantara/jembatan keuangan (financialintermediatery institution) menjadi sangat penting. Perbankan dituntut mempunyao kinerja yang bagus selakuperannya sebagai lembaga media/intermediasi, karena dengan hal tersebut maka bank mendapatkan "trust" dari masyarakat (agent of trust). Bank sebagai lembaga keuanganharus di dukung denganrasa kepercayaan dari para nasabah. Kegiatan oeprasionak bank yang lancar akan menentukan sebagai faktor pendukung kesejahteaan stakeholder dan peningkatan nilai perusahaan.

Klasifikasi peran pemerintah di era perekonomian modern dapat dibagi dalam tiga ketogori mulai dari alokasi, distribusi dan stabilisasi. ${ }^{5}$ Tugas pokok pemerintah, antara lain pembangunan landasan hukum; pemeliharaan lingkungan kebijakan yang tidak mendistorsi, kestabilan ekonomi makro,layanan investasi dan infrastruktur sosial,perlindungan kelompok yang lemah dan perlindungan lingkungan. Secara spesisifk dalam literatur ekonomi makro dijelaskan bahwa ada 2 bentuk kebijakan pemerintah dalam perekonomian, yaitu kebijakan moneter dan kebijakan fiskal.Kebijakan moneter merupakan kebijakan yang mempunyai tujuan memberi pengaruh pada kinerja perekonomiandari instrumen variabel jumlahuang beredar, sedangkan kebijakan fiskaladalah kebijakankebijakan yang mempunyai tujuan memberi pengaruh kegiatan ekonomi dengan intrumenvariabel penerimaan (pajak) dan pengeluaranpemerintah.

${ }^{5}$ Yuni Prihadi Utomo, Bambang Setiaj, "Efektifitas Pengaruh Kebijakan Moneter Dalam Kinerja Sektor Perbankan", Jurnal Ekonomi Manajemen Sumber Daya Vol. 13, No. 1, Juni 2012, hal 2. 
Perkembangan sektor perbankan yang dinamis sebagai faktor penentu pembangunan ekonomi di suatu negara. Sektor perbankan yang terpuruk berdampak sektor ekonomi juga terpuruk. Demikian juga, stagnansi kegiatan perekonomian akan berimbas pada sektor perbankan karena fungsi intermediasi tidak berjalan normal. ${ }^{6}$ Pemerintah mengemban tugas penting khususnya di bidang ekonomi,yaitu stabilitas ekonomi yang terpenuhi. Kegiatan pembangunan ekonomi akan mudah dilaksanakan apabila stabilitas ekonomi juga terpenuhi.Banyak jalan untuk mengusahakan stabilitas ekonomi, namun kebijakan fiskal dan kebijakan moneter pasti akan selalu akan bersinggungan. Kebijakan fiskal memuatkeseluruhan instrumen ekonomi dengan menggunakansumber daya anggaran negara (APBN). Sedangkan, kebijakan moneter terkait dengan pengendalianekonomi dengan instrumen suku bunga,inflasi, uang beredar, nilai tukar, dan lain sebagainya. ${ }^{7}$

Berdasarkan uraian diatas dapat diidentifikasikan masalah yang diangkat adalah "Bagaimanakah kebijakan pemerintah dalam menangani kasus pandemi covid-19 ini dan bagaimana dampak kebijakan pemerintah tersebut terhadap kinerja perbankan di Indonesia?".Berdasarkan pokok masalah dalam penelitian ini, maka menunjukkan bahwa tujuan penelitian ini adalah untuk mengetahui bagaimana kebijakan pemerintah dalam menangani kasus covid-19 serta mengetahui bagaimana kinerja ekonomi perbankan atas kebijakan-kebijakan pemerintah terhadap pandemi covid 19 tersebut.

\section{METODE PENELITIAN}

Tulisan ini merupakan hasil dari penelitian hukum yang menggunakan metode penelitian normatif, yaitu penelitian yang dilakukan dengan mengkaji ketentuan peraturan perundang-undangan yang berlaku

${ }^{6}$ Utami Baroroh, “Analisis Sektor Keuangan Terhadap Pertumbuhan Ekonomi Regional di Wilayah Jawa: Pendekatan Model Levine”, Jurnal Etikonomi Vol. 11 No. 2 Oktober 2012, hal 181.

${ }^{7}$ Ahmad Erani Yustika, "Kebijakan Moneter, Sektor Perbankan, dan Peran Badan Supervisi”, Jurnal Keuangan dan Perbankan, Vol. 14, No. 3 September 2010, hal. 447. di Indonesia dengan penelaahan melalui studi kepustakaan. Pengumpualan data sekunder dilakukan dengan sumber yaitu : pengumpulan bahan hukum sekunder, primer, dan tersier.

\section{PEMBAHASAN}

\section{A. Kebijakan Pemerintah Dalam Menangani Covid-19}

Perkembangan kondisi Covid-19 di Indonesia yang selalu meningkat dari waktu ke waktu. Pemerintah Pusat berkerja sama dengan Pemerintah Daerah senantiasa mencari solusi permasalahan secara efektif. Adanya kebijakan pembatasan sosial (social distancing) yang harus diterapkan, dengan pengurangan mobilisasi orang, aturan jaga jarak, dan pengurangan kerumuman orang yang beresiko meningkatan penyebaran Covid-19, misalnya segala hal dilakukan di rumah mulai dari sekolah, belajat, bekerja dan beribadah dilakukan dalam rangka menguransi tingkat penyebaran Covid-19 dengan tetap menjaga pelayanan kepada masyarakat, baik itu dalam memenuhi kebutuhan pokok, layanan kesehatan, dan layanan-layanan publik lainnya. Selain itu moda-moda transportasi umum juga dibatasi oleh pemerintah.Rendahnya rasa disiplin masyarakat Indonesia menyebabkan kebijakan social distancing atau jaga jarak sepertinya kurang berhasil. Jika ingin berhasil, harus didukung dengan penegakan hukum bagi pelanggar jaga jarak harus. Kebijakan jaga jarak harus tetap memperhatikan pekerja sektor informal, antara lain pihak-pihak yang tidak dapat bekerja di rumah yaitu pedagang kaki lima, pengendara atau pengemudi online dan industri lainnya.Dengan adanya karantina maka terdapat konsekuensi penutupan wilayah secara keseluruhan, tempat publik yang dikosongkan dan kebutuhan hidup ditanggung oleh negara. ${ }^{8}$ Selama proses karantina, kota didisinfektan dan warga disembuhkan.

Pandemik Covid-19 telah menekan ekonomi sejumlah negara, termasuk Indonesia. Virus corona ini menjadi beban

${ }^{8}$ Pasal 55 ayat (1) Undang-Undang Republik Indonesia No. 6 Tahun 2018 Tentang Kekarantinaan Kesehatan 
bagi ekonomi Indonesia. Beberapa sektor seperti pariwisata dan perdagangan perlahan mati karena terinfeksi virus corona. ${ }^{9}$ Dalam rangka pencegahan terjadinya resesi ekonomi akibat covid-19 maka dilakukan relaksasi di sektor perbankan, instrumen dan intervensi fiskal di sektor fiskal dan sebagain besar negara melakukan cara agar pandemi Covid19 tidak berdampak sangat dalam pada sektor ekonomi.Sehingga krisis kesehatan yang saat ini terjadi sedapat mungkin tidak berdampak pada krisis ekonomi, sosial dan keuangan. Dampak virus corona ini sudah mulai terasa bagi perekonomian dalam negeri. Salah satu contohnya adalah terus melemahnya nilai tukar rupiah. Pemerintah telah mempersiapkan anggaran dalam keputusan lockdown, anggaran tersebut termasuk sumber daya yang mencukupi terkait bahan pokok makanan agar kepanikan masyarakat tidak muncul apabila keputusan lockdown harus dilakukan.

Bank sebagaimana disebutkan dalam UU Perbankan No. 10/1998 merupakan badan usaha penghimpun dana dari masyarakat dan menyalurkan kembali dalam bentuk kredit dan atau bentuk-bentuk lain dalam rangka meningkatkan taraf hidup orang banyak.Bank merupakan lembaga keuangan yang kegiatannya sebagai penghimpun dana masyarakat dan sebagai penyalur ke masyarakat serta menyediakan jasa-jasa Bank lainnya. ${ }^{10}$ Kredit diberikan oleh Bank dengan bertujuan memenuhi kebutuhan masyarakat yang senantiasa meningkat, sedangkan kemampuan mempunyai batasan sehingga membutuhkan bantuan modal dalam rangka meningkatkan taraf hidup. ${ }^{11}$

Dalam pelaksanaannya, Bank tidak terlepas dari prinsip kepercayaan dan kehatihatian dalam memberi kredit kepada debitur guna menekan risiko terjadinya risiko kredit

${ }^{9}$ Taufik Fajar; Jurnalis, “Komentar Sri Mulyani soal Dampak Covid-19 ke Ekonomi RI”, okefinance; Senin 30 Maret 2020, hal 3, pukul 08:26 WIB

${ }^{10}$ Wisnu P. Setiyono, Miftakhul Nur Aini, “Analisis Kinerja Keuangan Perbankan Dengan Menggunakan Metode Camel (Studi Kasus Pada PT. BPR Buduran Delta Purnama)",Jurnal Bisnis, Manajemen \& Perbankan Vol. 1 No. 2, hal 177.

${ }^{11}$ Daeng Naja, 2005, Hukum Kredit dan Bank Garansi, PT Citra Aditya Bakti, Bandung, hlm. 6 bermasalah. $^{12}$ Adapun penggolongan kolekbilitas kredit terdapat 5 kriteria yaitu: ${ }^{13}$

1. Kredit lancar merupakan kredit yang siklus pembayarannya selalu tepat waktu baik pokok dan/ atau bunga;

2. Kredit dalam perhatian khusus merupakan kredit yang siklus pembayarannya terdapat tunggakan kurang dari 90 hari baik pokok dan/atau bunga;

3. Kredit kurang lancar merupakan kredit yang siklus pembayarannya terdapat tunggakan lebih dari 90 hari baik pokok dan/atau bunga;

4. Kredit yang diragukan merupakan kredit yang siklus pembayarannya terdapat tunggakan lebih dari 180 hari baik pokok dan/atau bunga;

5. Kredit macet merupakan kredit yang siklus pembayarannya terdapat tunggakan lebih dari 270 hari baik pokok dan/atau bunga;

Bank memegang peranan penting sebagai upaya peningkatan pertumbuhan ekonomi dan kesejahteraan masyarakat. Bank merupakan lembaga keuangan sebagai penghimpun dana antara lain deposito, giro, tabungan atau simpanan lain, kemudian menyalurkannya kembali kepada masyarakat yang membutuhkan dana melalui penjualan jasa keuangan yang pada gilirannya dapat meningkatkan kesejahteraan rakyat banyak. Peranan Bank bagi dunia usaha sangat kuat, baik peranan dalam lalu lintas pembayaran, penghimpun dana maupun penyalur dana.Salah satu sumber pendanaan perusahaan adalah Bank, sehingga gagalnya bank dapat berimbaskepada perusahaanperusahaan diluar sektor keuangan. Bank sebagai lembaga perantara penghimpun dana dari pihak ketiga yaitu masyarakat.inevestor yang menaruh dananya di Bank sebagai investasi, kemudian sebaagi penyalur dana ke pihak (masyarakat) yang membutuhkan dalam bentuk kredit. ${ }^{14}$

\footnotetext{
${ }^{12}$ Sutarno, 2009, Aspek-aspek Hukum Perkreditasn Pada Bank, Alfabeta, Bandung, hlm. 93

${ }^{13}$ Hermansyah, 2009, Hukum Perbankan Nasional Indonesia, Kencana, Jakarta, hlm. 66

${ }^{14}$ Filifus A. G. Suryaputra, dkk, “Perkembangan
}

Penelitian Kinerja Perbankan di Indonesia”, Jurnal 
Dana Moneter Internasional (IMF) menyatakan dengan adanya Covid-19 menyebabkan krisis pada ekonomi dan keuangan global. Hal ini dikarenakan, penyebaran virus ini telah melumpuhkan ekonomi dan penyebarannya sangat luas ke seluruh negara. Sektor yang terdampak pertama oleh krisis tersebut adalah sektor produksi dan pengeluaran. Dampaknya,tingkat konsumsi dan daya beli masyarakat bakal juga terdampak apabilapemerintah tidak mengantisipainya dengan baik. Pendorong pergerakan roda perekonomian salah satunya dari tingkat konsumsi rumah tangga, akan tetapi konsumsi rumah tangga juga mengaami kelambatan laju pertumbuhan. Terjadinya penurunan daya beli mengingat dampak Covid-19 cukup signifikan di hampir seluruh sektor ekonomi. Pasar keuangan Indonesia juga dipengaruhi oleh tingkat produksi perusahaan mulai dari arus keuangan sampai dengan kredit perbankan.Pemerintah, Bank Indonesia,OJK dan otoritas terkait harus saling bersinergi untuk memitigasi risiko Covid-19 pada sektor ekonomi. Dalam perkembangannya, BI telah menggelontorkan beberapa kebijakan moneter mulai dari suku bunga yang dipangkas, triple intervention, GWM dipangkas dan convergent ratedengan tujuan untuk sistem keuangan tetap terjaga di tengah guncangan Covid-19. Adapun elemen pendukung pertumbuhan ekonomi selalu berkesinambungan yaitusinergi, transformasi, dan inovasi.

Aktivitas ekonomi dalam negeri semakin tertekan akibat penyebaran virus corona. Lambatnua aktivitas ekonomi itu akan berampak pada penyaluran kredit perbankan dan kualitas asetnya, termasuk ke segmen korporasi. Sensivity analysis dilakukan Bank Mandiri berdasar POJK relaksasi kredit untuk menjaga NPL dalam kondisi aman dengan melakukan penilaian/ assesment terhadap debitur-debitur yang termasuk debitur terdampak Covid-19 dan harus diberikan restrukturisai.

Beberapa jurnal internasional tentang perbankanjuga menjelaskan :

Akuntansi dan Bisnis Vol. 17 No. 2, Agustus 2017, hal 88.
"NPL is a common indicator to measure credit risk as it directly affects the bank-ing system. The 1997 Asian financial crisis and the 2007 global crisis are the two examples that best explain how NPL can affect the financial system." $N P L s$ are important because they reflect the credit quality of the loan portfolio of banks, and in aggregate terms, reflect the credit quality of the loan portfolio of the banking sector in a country. An understanding of the factors that influence the level of NPLs is crucial for the risk management function of banks and for financial stability. ${ }^{16} \mathrm{NPL}$ (Non Performing Loan) merupakan indikator penilaian risiko kredit yang ada di sebuah bank. Tingkat kesehatan sebuah bank ditentukan oleh grafik dari NPL yang ada, apakah tingkat risiko kreditnya tinggi atau rendah. Bahkan dari data yang ada, NPL dapat mempengaruhi sistem keuangan.

OJK No. 11/POJK.03/2020 diterbitkan oleh Otoritas Jasa Keuangan (OJK) bertujuan memberikan stimulus perekonomian. Stimulus ini berlaku 13 Maret 2020 s/d 31 Maret 2021 bagi industri perbankan.Identifikasi debitur yang terdampak harus dilakukan oleh Bank secara proaktif sehingga kebijakan stimulus OJK dapat berjalan secara optimal. POJK dikeluarkan untuk membantu para debitur yang terdampak akibat corona akibat kinerja dan kapasitas yang menurundan untuk mencegah adanya peningkatkan risiko kredit yang dapat mengganggu kinerja perbankan dan stabilitas sistem keuangan.

Kredit macet merupakan kondisi debitur tidak dapat melunasi kredit sesuai perjanjian yang telah disepakati sebelumnya dengan pihak bank, kategorinya berupa ketidakmampuan pembayaran angsuran sama sekali, hanya dapat memenuhi pembayaran angsuran sebagian, bahkan melakukan pembayaran setelah perjanjian kredit

\footnotetext{
${ }^{15}$ Laxmi Koju, Ram Koju, Shouyang Wang. "Macroeconomic and Bank Specific Determinants of Non Performing Loans : Evidence from Nepalese Banking System". Journal of Central Banking Theory and Practice, Oktober 2017, hlm. 112

${ }^{16}$ Peterson K. Ozili. "Non-performing loans and financial development new evidence". The Journal of Risk Finance Vol 20 No 1, 2019, hlm.
} 
berakhir. ${ }^{17}$ Kebijakan stimulus yang telah ada diharapkan dapat dapat menekan kredit macet yang ada dan kemudahan dalam pemberian kredit baru. POJK ini juga diharapkan menjadi bisa mendorong kinerja perbankan sebagai intermediasi, kestabilan sistem keuangan dan pertumbuhan ekonomi secara optimal. Pemberian stimulus OJK ini diberikan dengan prinsip kehati-hatian dan pencegahan terjadinya penyalahgunaan (moral hazard) serta diberikan kepada debitur yang terdampak. Kebijakan stimulus yang dimaksud terdiri dari:

1. Penilaian kolekbilitas kredit dengan plafon kredit s/d Rp 10 miliar berdasar pembayaran pokok dan/atau bunga.

2. Peningkatan kolekbilitas kredit menjadi lancar dengan melakukan restrukturisasi tanpa adanya batasan plafon dan jenis debitur.

Relaksasi pengaturan ini diberlakukan dalam jangka waktu satu tahun bagi debitur Non-UMKM dan UMKM. Terkait mekanisme penerapannyadikembalikan kepada kebijakan masing-masing bank dan sesuai dengan kapasitas membayar debitur.OJK juga merilis aturan bagi idustri keuangan non Bank dalam rangka menahan efek lanjut pandemi virus corona dengan pemberian relaksasi kepada nasabah. Selain itu, OJK juga mengeluarkan aturan penanganan masalah di industri perbankan.

\section{B. Kinerja Perbankan Atas Kebijakan Pemerintah Dalam Menangani Covid-19}

Salah satu faktor penentu keberhasilan sistem ekonomi di Indonesia dipegang oleh sektor perbankan yang merupakan jantung dalam sistem perekonomian Indonesia. Pemegang fungsi intermediasi maka Bank sebagai penghimpun dananya masyarakat dan sebagai penyalur kembali ke masyarakat dengan kredit kepada sektor-sektor usaha dalam rangka membantu pengembangan usaha sebagai penunjang terlaksananya pembangunan nasional dalam rangka mewujudkan pembangunan yang merata, pertumbuhan ekonomi yang meningkat dan kestabilannasional, serta taraf hidup rakyat

${ }^{17}$ Gatot Supramono, 2009, Perbankan dan Masaah Kredit : Suatu Tinjauan di Bidang Yuridis, Rineka Cipta, Jakarta, hlm. 32 yang meningkat. Bank sebagai lembaga yang memegang posisi penting harus senantiasa mencapai kinerja serta kontiuitasnya selalu terjaga. ${ }^{18}$ Perbankan Indonesia dituntut untuk melakukan peningkatan kinerja keuangan supaya bertahan dan bersaing dalam ketatnya kativitas bisnis perbankan.

Keseluruhan kinerja bank adalahbentukgambaran prestasi pencapaian bank dalam melaksanakan operasionalnya, dari segi keuangan, segi pemasaran, segi penghimpun dana, dan penyaluran dana, teknologi dan segi SDM. Kinerja keuangan bank terdiri dari kegiatan bank pada periode mencakup segi funding (penghimpunan dana) dan landing (penyaluran dana)kemudian menggunakan indikator pengukuran dari segi kecukupan modal, likuiditas dan profitabilitas bank. Pengukuran kinerja keuangan dapat dilakukan dengan melakukan analisis dan evaluasi laporan keuangan. Data posisi dan kinerja keuangan dimasa lalu yang kemudian menjadi tolak ukur sebagai prediksi posisi dan kenerja keuangan di masa yang akan datang. ${ }^{19}$ Kinerja bank sangat dipengaruhi faktor internal dan $\mathrm{f}$ eksternal. Faktor internal merupakan faktor yang dikendalikan manajemen yang mempengaruhi kinerja bank. Sedangkan faktor eksternal merupakan faktor yang tidak dapat dikendalikan manajemen, seperti faktor makroekonomi dan karakteristik industri. Faktor-faktor tersebut adalah Efisiensi Operasi (BOPO), Risiko Kredit (NPL), Risiko Pasar (NIM), Permodalan (CAR), dan Likuiditas (LDR), faktor-faktor ini merupakan faktor-faktor dari dalam yang mempengaruhi kinerja bank. ${ }^{20}$

Respon beberapa bank milik negara yaitu Bank BRI, Bank Mandiri, Bank BTN

${ }^{18}$ Fany Indriyani, "Komparasi Kinerja Perbankan Syariah dengan Bank Konvensional: Suatu Studi Literatur" Volume 6 Nomor 2, Desember 2015 hal. 110.

${ }^{19}$ Endi Sarwoko, “Analisis Kinerja Bank Swasta Nasional Devisadan Non Devisa di Indonesia”, Jurnal EkonomiModerenisasiI, Volume 5, Nomor 2, Juni 2009, hal. 94

${ }^{20}$ Didik Purwoko dan Bambang Sudiyatno, "FaktorFaktor Yang Mempengaruhi Kinerja Bank (Studi Empirik Pada Industri Perbankan di Bursa Efek Indonesia)", Jurnal Bisnis dan Ekonomi, Vol. 20 No. 1 , hal. 26 
dan Bank BNI yang terhimpun dari HIMBARA (Himpunan Bank Milik Negara) mendukung kebijakan OJK yang telah menerbitkan kebijakan stimulus pada sektor perbankan supaya tetap bertahan dan berjalan di masa pandemi Covid-19.Dukungan diberikan dalam bentukkomitmen dalam penerpakan kebijakan stimulus tersebut untuk para pelaku Usaha Mikro, Kecil dan Menengah (UMKM) di Indonesia tetap terjaga dan terselamatkan dari dampak virus corona. $^{21}$ Tiap-tiap bank telah menyiapkan kebijakan internal masing-masing untuk di implemantasikan kebijakan stimulus OJK tersebut. Teknis pelaksanannya, penilaian terhadpa nasabah/debitur yang terdampak harus dilakukan oleh tiap-tiap bank dalam penentuan tingkat restrukturisasi kreditnya apakah berada pada level berat, sedang, ringan atau tidak perlu dilakukan restrukturisasi.Restrukturisai diterapkan pada debitur yang memang berhak yang dimana kondisi debitur terdampak secara langsung/tidak langsung baik pada sektor ekonomi, transportasi, parisiwata, perhotelan, perdagangan, pertanian, pertambangan maupun pengolahan.Hal itu dilakukan agat roda perekonomian tetap berjalan walaun telah terkontraksi dengan adanya pandemi Covid-19.Skema restrukturisasi akan dilakukan Himbara bagi debitur UMKM, antara lain berupa suku bunga yang diturunkan, jangka waktu yang ditambah, jadwal angsuran pokok dan/atau bungayang diatur/dijadwalkan kembali serta keringanan bunga sesuai dengan kondisi debitur.Adapun syarat yang harus dipenuhi oleh debitur guna memperoleh fasilitas restrukturisasi tersebut yaitu pertama dengan permohonan ajuan restrukturisasi kepada Bank yang terkait, kemudian berdasar permohonan debitur tersebut maka Bank akan menetapkan level restrukturisasinya berdasar penilaian dampak yang terjadi pada debitur yang bersangkutan.Bank akan menetapkan jenis restrukturisasi sesuai dengan dampak yang terjadi pada usaha debitur akibat Covid-19.

${ }^{21}$ Reza, “HIMBARA Dukung Kebijakan Pemerintah
Menanggulangi Dampak Covid-19", Jakarta: Liputan6.com, Senin, 30 Mar 2020, pukul 10:11 WIB.
Perekonomian di dunia sangat terdampak akibat adanya wabah virus corona salah satunya Indonesia. Bursa efek Indonesia (BEI) juga mengalami guncangan, industri manufaktur, UMKM, industri keuangan, pendapatan masyarakat secara individu juga turut terdampak gelombang wabah corona ini. Hal ini yang menjadi dasar, negara-negara menggolontorkaan stimulus ekonomi dalam rangka pengurangan dampak perekonomian yang semakin turun.Para pelaku usaha baik mikro dan makro sangat merasakan beratnya roda usaha yang berjalan dan terkendala untuk mengangsur kredit mereka di bank secara tepat waktu. Hal lain juga dirasakan oleh sektor transportasi online yang mengalami penurunan pendapatan dengan adanya wabah ini.Pola kehidupan yang berubah dengan adanya social distancing dan physical distancing menganjurkan semua masyarakat melakukan segala hal yang bisa dilakukan di rumah antara lain berkerja dari rumah, belajar dari rumah dan beribadah di rumah.Kenaikan jumlah kredit macetpun juga sangat tinggi karena akhirnya banyak debitur yang tidak mampu membayar angsuran dengan tepat waktu bahkan tidak mampu mengembalikan hutangnya secara lunas.Beratnya tantangan yang dialami oleh sektor-sektor industri termasuk UMKM. BUMN dalam hal ini bertugas aspek kesehatan dan juga mendukung sistem iklim perekonomian yaitu sektor usaha dan moneter. Dalam rangka membantu sektor-sektor industri yang terdampak maka Kementerian BUMN menerbitkan beberapa kebijakan dengan berkoordinasi dengan lembaga terkait.Bankbank BUMN tentunya diminta untuk melakukan penurunan suku bunga bagi industri sektor usaha, selain itu dapat juga diajukan kebijakan relaksasi kredit yang dikeluarkan oleh OJK bagi sektor-sektor lain yang terdampak antara lain perhotelan, restoran/rumah makan, penerbangan dan lain sebagainya. Pemerintah juga akan mengeluarkan obligasi-obligasi khususnya obligasi dari perusahaan BUMN yang ratingnya bagus, seperti BRI dan Mandiri dalam rangka membantu devisa.

Ditegah penyebaran pandemi Covid19 yang mulai memukul sektor riil dan keuangan, kinerja perbankan ditanah air pada 
kartal pertama masih positif (masih cukup kuat) baik dari sisi permodalan maupun kualitas kredit.BI selaku pemegang utama kestabilitan mata uang rupiah dan inflasi maka BI telah mengeluarkan kebijakankebijakan moneter terkait kondisi ekonomi yang semakin melemah saat ini. Diharapkan dapat dilakukan penurunan suku bunga acuan perbankan sehingga dapat membawa angin segar ke industri perbankan untuk ikut penurunan ini.Gubernur BI mengatakan kebijakan moneter di tengah wabah corona saat ini tetap akomodatif dan konsisten dengan prakiraan inflasi yang terkendali dalam kisaran sasaran. Dengan melihat kondisi ekonomi seperti ini, kemungkinan kinerja perbankan akan sedikit menurun paling tidak setahun kedepan. Namun, BI tetap berupaya untuk menjaga pertumbuhan ekonomi dengan memperhatikan stabilitas eksternal yang terjaga di kala perekonomian global terus melambat.

\section{SIMPULAN}

Perkembangan penyebaran Covid-19 secara global yang selalu meningkat dan Indonesia merupakan satu diantara negara lain yang terdampak Covid-19. Covid-19 tidak hanya menyebabkan guncangan krisis kesehatan, akan tetapi juga menimbulkan guncangan pada seluruh sektor ekonomi, pendidikan dan sosial. Dalam mengatasi dampak Covid ada beberapa negara yang menerapkan lockdown dan semi lockdown.Indonesia sendiri memang tidak menerapkan lockdown akan tetapi menerapkan physical distancing yaitu memfokuskan segala kegiatan di rumah. Tanpa adanya kebijakan lockdown,ternyata berpengaruh pada ekonomi masyarakat, terutama sektor usaha/UMKM.Sektor usaha mengalami kendala menjalankan roda usahanya dengan adanya physical disatncing, terjadinya penurunan produksi, daya beli masyarakat menurun sehingga sektor usaha yang mempunyai pinjaman di sebuah Bank mengalami kendala untk mengangsur/melunasinya. Hal ini akan berdampak pada sektor perbankan dengan meningkatnya jumlah kredit macet (NPL). Stimulu-stimulus dalam sektor ekonomi sangat penting sebagai pendorong kinerja perbankan secara optimal, sistem keuangan yang terjaga dan pertumbuhan ekonomi yang meningkat. Diterbitkannya kebijakankebijakan stimulus oleh pemerintah khusunya di sektor perbankan sangat membawa angin segar bagi sektor industri. POJK terkait relaksasi kredit berupa peningkatan kualitas kolebilitas kredit dan restrurturisasi kredit bagi debitur yang terdampak. Melihat keadaan masyarakat sekarang ini tengah mengalami krisis ekonomi, terutama masyarakat UMKM maka OJK memberikan stimuluskepada debitur yang terdampak penyebaran Covid-19 dalam sistem perbankan.

\section{SARAN}

Dengan adanya kebijakan tersebut pemerintah mengharapkan agar debitur dapat melakukan kewajibannya dalam pembayaran kredit. Hal ini guna untuk menjaga stabilitas keuangan (perbankan) agar tidak mengalami pemerosotan.Pemerintah juga mengharapkan agar debitur dapat melaksanakan dengan baik kebijakan yang telah dibuat oleh pemerintah tersebut, karena kinerja debitur juga akan berpengaruh terhadap kinerja perbankan.

\section{DAFTAR PUSTAKA}

Buku, Artikel :

Baroroh, Utami. "Analisis Sektor Keuangan Terhadap Pertumbuhan Ekonomi Regional di Wilayah Jawa: Pendekatan Model Levine”, Jurnal Etikonomi Vol. 11 No. 2 Oktober 2012.

Daeng Naja, Hukum Kredit dan Bank Garansi, PT Citra Aditya Bakti, Bandung. 2005

Gatot Supramono, Perbankan dan Masaah Kredit : Suatu Tinjauan di Bidang Yuridis, Rineka Cipta, Jakarta, 2009

Hermansyah, Hukum Perbankan Nasional Indonesia, Kencana, Jakarta, 2009

Indriyani, Fany. "Komparasi Kinerja Perbankan Syariah dengan Bank Konvensional: $\quad$ Suatu Studi Literatur" Volume 6 Nomor 2, Desember 2015. 
Laxmi Koju, Ram Koju, Shouyang Wang. "Macroeconomic and Bank Specific Determinants of Non Performing Loans : Evidence from Nepalese Banking System". Journal of Central Banking Theory and Practice, Oktober 2017

Peterson K. Ozili. "Non-performing loans and financial development new evidence". The Journal of Risk Finance Vol 20 No 1, 2019

Purwoko, Didik., Bambang Sudiyatno. "Faktor-Faktor Yang Mempengaruhi Kinerja Bank (Studi Empirik Pada Industri Perbankan di Bursa Efek Indonesia)", Jurnal Bisnis dan Ekonomi, Vol. 20 No. 1.

Sarwoko,Endi. "Analisis Kinerja Bank Swasta Nasional Devisadan Non Devisa di Indonesia”, Jurnal EkonomiModerenisasiI, Volume 5, Nomor 2, Juni 2009.

Setiyono, P. Wisnu, Miftakhul Nur Aini. "Analisis Kinerja Keuangan Perbankan Dengan Menggunakan Metode Camel (Studi Kasus Pada PT. BPR Buduran Delta Purnama)",Jurnal Bisnis, Manajemen \& Perbankan Vol. 1 No. 2.

Suryaputra, Filifus A. G., dkk. "Perkembangan Penelitian Kinerja Perbankan di Indonesia”, Jurnal Akuntansi dan Bisnis Vol. 17 No. 2, Agustus 2017.

Sutarno, Aspek-aspek Hukum Perkreditasn Pada Bank, Alfabeta, Bandung. 2009

Utomo, Yuni Prihadi., Bambang Setiaj. "Efektifitas Pengaruh Kebijakan Moneter Dalam Kinerja Sektor Perbankan", Jurnal Ekonomi Manajemen Sumber Daya Vol. 13, No. 1, Juni 2012.

Yustika, Ahmad Erani. "Kebijakan Moneter, Sektor Perbankan, dan Peran Badan Supervisi”, Jurnal Keuangan dan Perbankan, Vol. 14, No. 3 September 2010.
Peraturan UU :

UU Perbankan No. 10 tahun 1998 Perubahan UU No. 7 tahun 1992

Undang-Undang Karantina Kesehatan No. 6 Tahun 2018

Undang-undang Pencegahan dan Penanganan KrisisSistem Keuangan No. 9 Tahun 2016

POJK Stimulus Perekonomian Nasional No. 11/POJK/POJK 03/2020

POJKKebijakan Countercyclical Lembaga Jasa Non Bank No. 14/POJK. 05/2020

POJK Perintah Tertulis Penanganan Masalah Bank No 18/POJK. 03/2020

Internet :

Agustin, Alin. "Dampak Pandemi Covid-19 Pada Pertumbuhan Ekonomi Indonesia”, Bale Warga, Sabtu, 28 Mar 2020, pukul 12:40 WIB; https://sukabumiupdate.com/detail/ba le-warga/opini/66831-DampakPandemi-Covid-19-PadaPertumbuhan-Ekonomi-Indonesia

Reza. "HIMBARA Dukung Kebijakan Pemerintah Menanggulangi Dampak Covid-19", Jakarta: Liputan6.com, Senin, 30 Maret 2020 pukul 10:11 WIB;

https://www.liputan6.com/bisnis/read /4214439/himbara-dukungkebijakan-pemerintahmenanggulangi-dampak-covid-19 